Jurnal e-GiGi (eG), Volume 2, Nomor 2, Juli-Desember 2014

\title{
GAMBARAN TINGKAT PENGETAHUAN SISWA SMA NEGERI 1 MANADO TENTANG DAMPAK MEROKOK BAGI KESEHATAN GIGI DAN MULUT
}

\author{
${ }^{1}$ Meriza Kharis Novitasari \\ ${ }^{2}$ Vonny Wowor \\ ${ }^{3}$ Wulan P. J. Kaunang \\ ${ }^{1}$ Mahasiswa Program Studi Pendidikan Dokter Gigi Fakultas Kedokteran \\ ${ }^{2}$ Fakultas Kedokteran Universitas Sam Ratulangi \\ ${ }^{3}$ Program Studi Pendidikan Dokter Gigi Fakultas Kedokteran Universitas Sam Ratulangi \\ Universitas Sam Ratulangi Manado \\ Email: kmeriza23@gmail.com
}

\begin{abstract}
Smoking is a habit that is very common among the people. Today many children and teen who become active smokers. The factors underlying the smoking habit in adolescents one of which is the lack of knowledge about the effects of smoking adolescents. Smoking can have an impact on oral health such as the oral cavity disease, gingivitis, discoloration of the teeth and others. The purpose of this study was to determine the level of students knowledge of Public Senior High School 1 Manado on the effects of smoking on oral health. This type of research was a descriptive type with a crosssectional study involving 100 respondents. The number of respondents in this research has taken using simple random sampling method. The collection of data was obtained through a questionnaire which includes characteristics of the respondents, level of knowledge about the effects of smoking on oral health. The results showed the level of students 'knowledge about the effects of smoking on oral health in general is quite good with a percentage of $96 \%$, the level of students' knowledge about the impact of smoking on dental health is quite good with a percentage of $89 \%$, the level of knowledge about the health effects of smoking on periodontal tissues categorized as either with the percentage of $68 \%$, and the health effects of smoking, oral mucosal tissue is also quite good with a percentage of $72 \%$. Conclusion: the average level of knowledge about the effects of smoking on oral health in both categories classified by the percentage of $81 \%$.
\end{abstract}

Keywords: Knowledge of students, the impact of smoking, oral health.

\begin{abstract}
Abstrak: Merokok merupakan kebiasaan yang sangat umum di kalangan masyarakat.Dewasa ini banyak anak-anak dan remaja yang menjadi perokok aktif.Faktor-faktor yang melatar belakangi kebiasaan merokok pada remaja salah satunya yaitu kurangnya pengetahuan remaja tentang dampak merokok.Merokok dapat memberikan dampak terhadap kesehatan gigi dan mulut seperti penyakit rongga mulut, gingivitis, perubahan warna pada gigi dan lain-lain.Tujuan penelitian ini untuk mengetahui tingkat pengetahuan siswa SMA Negeri 1 Manado tentang dampak merokok bagi kesehatan gigi dan mulut.Jenis penelitian ini bersifat deskriptif dengan pendekatan cross-sectional study yang melibatkan 100 responden.jumlah responden dalam penelitian ini diambil menggunakan metode simple random sampling. Pengumpulan data diperoleh melalui kuesioner yang meliputi karakteristik responden, tingkat pengetahuan mengenai dampak merokok terhadap kesehatan gigi dan mulut. Hasil penelitian menunjukkan tingkat pengetahuan siswa tentang dampak merokok bagi kesehatan gigi dan mulut secara umum tergolong baik dengan persentase $96 \%$, tingkat pengetahuan siswa tentang dampak merokok bagi kesehatan gigi tergolong baik dengan persentase $89 \%$, tingkat pengetahuan tentang dampak merokok terhadap kesehatan jaringan periodontal tergolong baik dengan persentase 68\%, dan dampak merokok bagi kesehatan jaringan mukosa mulut juga tergolong baik dengan persentase $72 \%$. Simpulan: rata-rata tingkat pengetahuan responden tentang dampak merokok bagi kesehatan gigi dan mulut tergolong dalam kategori baik dengan persentase $81 \%$.
\end{abstract}

Kata kunci: Pengetahuan siswa, dampak merokok, kesehatan gigi dan mulut. 
Merokok merupakan kebiasaan yang sangat umum di kalangan masyarakat, bahkan bagi golongan tertentu sudah merupakan gaya hidup. Kebiasaan merokok dapat ditemukan pada berbagai golongan usia, mulai dari anak-anak hingga dewasa. Saat ini banyak anak-anak dan remaja yang sudah menjadi perokok aktif.

Berdasarkan penelitian yang dilakukan oleh Global Youth Tobacco Surveydi Baghdad Irak tahun 2007, terdapat 39,5\% remaja laki-laki dan $16,1 \%$ remaja perempuan berumur 13-15 tahun sudah mulai mencoba merokok. ${ }^{2}$ Data World Health Organization (WHO) tahun 2008 menunjukkan Indonesia menduduki peringkat ke tiga dengan jumlah perokok terbesar di dunia setelah China dan India. ${ }^{1}$

Menurut data Kementerian Kesehatan Republik Indonesia, lebih dari sepertiga pelajar dilaporkan mulai terbiasa merokok.Ada tiga diantara sepuluh pelajar menyatakan pertama kali merokok pada usia dibawah 10 tahun. $^{3}$ Prevalensi perokok remaja Indonesia yang berusia 13-15 tahun mengalami peningkatan dari $12,6 \%$ di tahun 2006 menjadi 20,3\% pada tahun 2009. ${ }^{4}$ Data Riskesdas tahun 2010 menunjukkan adanya peningkatan persentase perokok aktif hingga mencapai $67 \%$ pada remaja laki-laki, dan $2,7 \%$ pada remaja perempuan dari jumlah penduduk. ${ }^{5}$

Merokok memiliki daya merusak yang cukup besar terhadap kesehatan. Menurut WHO rokok adalah penyebab berbagai penyakit pada perokok, baik perokok aktif maupun pasif. Telah banyak diteliti bahwa kebiasaan merokok berhubungan dengan terjadinya penyakit seperti kanker paru, penyakit kardiovaskuler, gangguan saraf, gangguan penglihatan, dan sebagainya. ${ }^{6}$

Rongga mulut merupakan jalan masuk utama untuk makanan, minuman, dan bahan-bahan lain, misalnya rokok. Kandungan rokok berupa tembakau, tar, nikotin, karbon monoksida, ammonia, dan derivat-derivat lainnya dapat mengiritasi rongga mulut saat dikonsumsi karena adanya pembakaran. ${ }^{7}$ Kebiasaan merokok merupakan salah satu pencetus timbulnya gangguan serta penyakit rongga mulut, antara lain dapat mengakibatkan gigi berubah warna, penebalan mukosa, gingivitis bahkan penyakit kanker mulut. ${ }^{8}$

Ada beberapa faktor yang melatar belakangi kebiasaan merokok pada remaja, salah satunya yaitu kurangnya pengetahuan remaja tentang dampakmerokok bagi kesehatan. Pengetahuan merupakan domain yang sangat penting bagi pembentukan perilaku seseorang. Tingkat pengetahuan remaja tentang kandungan rokok serta dampak yang dapat ditimbulkanpada gigi dan mulut dapat memengaruhi perilaku merokok pada remaja. ${ }^{9}$

SMA Negeri 1 Manado merupakan salah satu institusi pendidikan yang ada di kota Manado. Berdasarkan pengamatan penulis semasa bersekolah di SMA Negeri 1 Manado, banyak siswanya yangmemiliki kebiasaan merokok. Belum tersedianya data serta adanya kemudahan untuk mengakses data mendorong penulis untuk melakukan penelitian di SMA Negeri 1 Manado guna memperoleh gambaran tentang tingkat pengetahuan siswa tentang dampak merokok bagi kesehatan gigi dan mulut.

\section{BAHAN DAN METODE}

Jenis penelitian yang digunakan yaitu penelitian deskriptif dengan menggunakan pendekatan cross-sectional study.Penelitian ini dilaksanakan di SMA Negeri 1 Manado pada bulan April-September 2014.

Populasi dalam penelitian ini adalah siswa SMA Negeri 1 Manado, di kelas XI dengan jumlah populasi sebanyak 521 siswa.

Kriteria inklusi pada penelitian ini yaitu Siswa yang bersedia menjadi responden, dibuktikan dengan penandatanganan informed consent, Siswa yang hadir saat penelitian.

Pengambilan sampel dalam penelitian ini menggunakan metode simplerandom sampling, yaitu metode pengambilan sampel acak sederhana. Pengambilan sampel dilakukan dengan cara diundi sehingga setiap individu mempunyai kesempatan yang sama untuk diambil sebagai sampel, dan didapatkan 100 responden.Variabel 
Novitasari, Wowor, Kaunang; Gambaran Tingkat Pengetahuan Siswa SMA Negeri 1...

penelitian ini terdiri dari tingkat pengetahuan dan dampak merokok bagi kesehatan gigi dan mulut.

Pengetahuan responden yang meliputi pengetahuan tentang dampak merokok bagi kesehatan gigi dan mulut secara umum, kesehatan gigi, kesehatan jaringan periodontal dan kesehatanjaringan mukosa mulut di ukur dengan kuesioner yang berisi 18 pertanyaan, yang dikelompokkan menjadi 4 kelompok pertanyaan.Setiap pertanyaan diberikan nilai/skor 2 untuk jawaban Tahu, sedangkan nilai/skor 1 untuk jawaban Tidak tahu.

\section{HASIL PENELITIAN}

\section{Karakteristik responden}

Karakteristik responden dapat dilihat pada tabel 1, 2, 3, dan 4 .

Tabel 1. Distribusi frekuensi responden berdasarkan usia

\begin{tabular}{ccc}
\hline Usia & $\begin{array}{c}\text { Jumlah } \\
\text { responden (n) }\end{array}$ & $\begin{array}{c}\text { Persentase } \\
\mathbf{( \% )}\end{array}$ \\
\hline 15 tahun & 12 & 12 \\
16 tahun & 77 & 77 \\
17 tahun & 11 & 11 \\
Total & 100 & 100 \\
\hline
\end{tabular}

Tabel 1 menunjukkan bahwa dari 100 responden terdapat 12 responden (12\%) berusia 15 tahun, 77 responden (77\%) berusia 16 tahun dan 11 responden (11\%) berusia 17 tahun.

Tabel 2. Distribusi frekuensi responden berdasarkan jenis kelamin

\begin{tabular}{ccc}
\hline $\begin{array}{c}\text { Jenis } \\
\text { kelamin }\end{array}$ & $\begin{array}{c}\text { Jumlah responden } \\
\text { (n) }\end{array}$ & $\begin{array}{c}\text { Persentase } \\
\text { (\%) }\end{array}$ \\
\hline & & \\
Laki-laki & 40 & 40 \\
Perempuan & 60 & 60 \\
\hline Total & 100 & 100 \\
\hline
\end{tabular}

Tabel 2 menunjukkan bahwa dari 100 responden diketahui 40 responden (40\%) berjenis kelamin laki-laki dan 60 responden (60\%) berjenis kelamin perempuan.

Tabel 3. Distribusi frekuensi responden berdasarkan pekerjaan orangtua

\begin{tabular}{ccc}
\hline Pekerjaan & $\begin{array}{c}\text { Jumlah Responden } \\
\text { (n) }\end{array}$ & $\begin{array}{c}\text { Persentase } \\
\text { (\%) }\end{array}$ \\
\hline PNS & 32 & $32 \%$ \\
Swasta & 56 & $56 \%$ \\
Lain-lain & 12 & $12 \%$ \\
Total & 100 & $100 \%$ \\
\hline
\end{tabular}

Pekerjaan orangtua responden yang paling banyak dijumpai yakni bekerja sebagai pegawai swasta sebanyak 56 orang (56\%).Kategori pegawai negeri sipil (PNS) 32 orang (32\%), dan sebanyak 26 orang (26\%) berada pada kategori lain-lain.

Tabel 4. Distribusi frekuensi responden berdasarkan pendidikan orangtua

\begin{tabular}{ccc}
\hline $\begin{array}{c}\text { Pendidikan } \\
\text { Terakhir }\end{array}$ & $\begin{array}{c}\text { Jumlah } \\
\text { responden } \\
\text { (n) }\end{array}$ & $\begin{array}{c}\text { Persentase } \\
\text { (\%) }\end{array}$ \\
\hline SD & - & - \\
SMP & 7 & $7 \%$ \\
SMA & 39 & $39 \%$ \\
PT & 54 & $54 \%$ \\
\hline Total & 100 & $100 \%$ \\
\hline
\end{tabular}

Data pada Tabel 4 menunjukkan tingkat pendidikan orangtua yang paling banyak adalah lulusan PT yaitu sebanyak 54 responden (54\%), lulusan SMA 39 responden (39\%), sedangkan sebagian kecil lulusan SMP yakni sejumlah 7 responden $(7 \%)$.

Tingkat pengetahuan responden tentang dampak merokok bagi kesehatan gigi dan mulut. Tingkat pengetahuan responden dapat dilihat pada tabel distribusi 5, 6, 7, 8, dan 9 . 
Jurnal e-GiGi (eG), Volume 2, Nomor 2, Juli-Desember 2014

Tabel 5. Distribusi frekuensi tingkat pengetahuan responden tentang dampak merokok bagi kesehatan secara umum

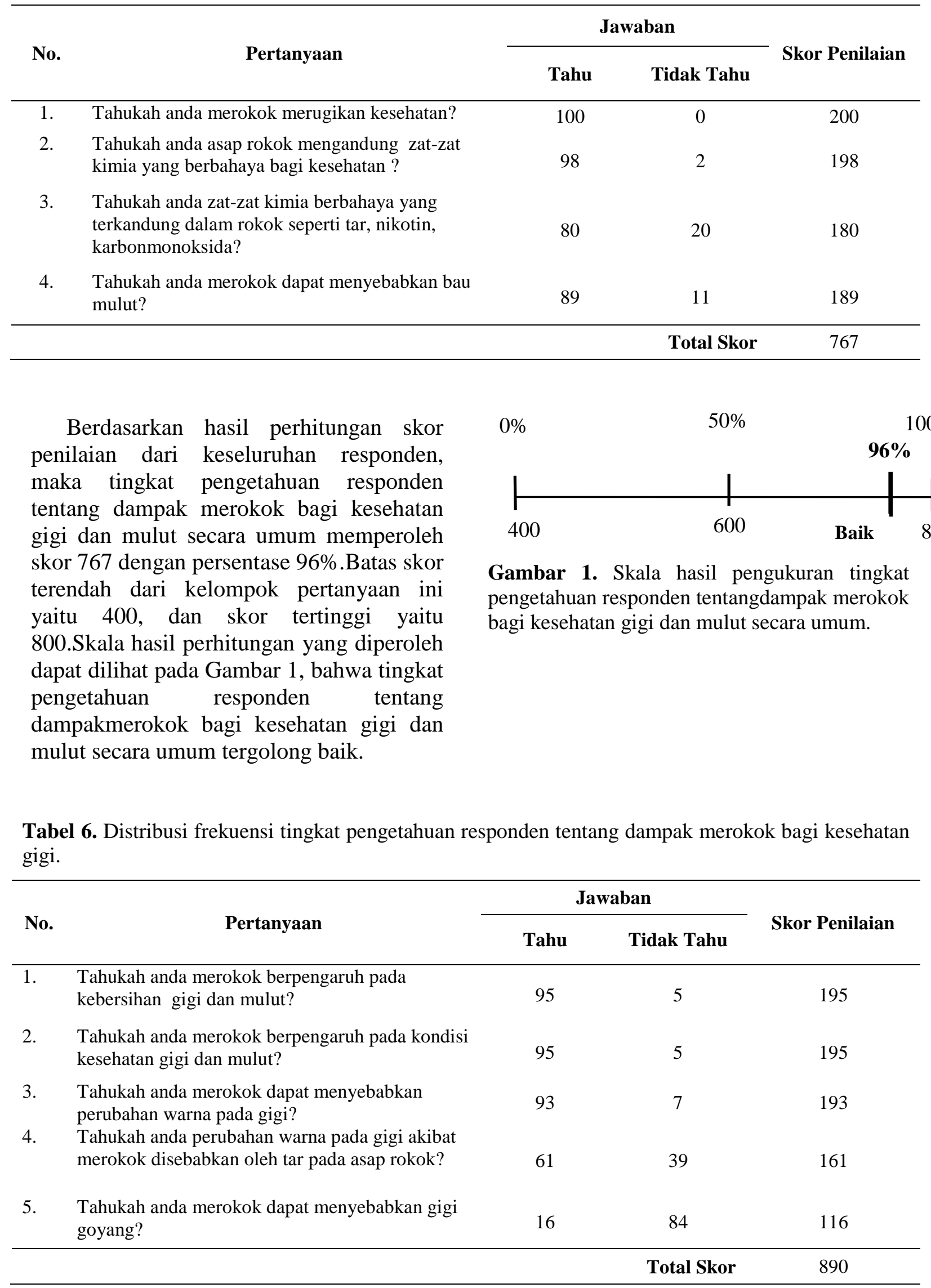


Novitasari, Wowor, Kaunang; Gambaran Tingkat Pengetahuan Siswa SMA Negeri 1...

Berdasarkan hasil perhitungan skor penilaian keseluruhan responden, maka tingkat pengetahuan responden tentang dampak merokok bagi kesehatan gigi memperoleh skor 890 dengan persentase 89\%. Batas skor terendah dari kelompok pertanyaan ini yaitu 500 dan skor tertinggi yaitu 1000. Skala hasil perhitungan yang diperoleh dapat dilihat pada Gambar 2, bahwa tingkat pengetahuan responden tentang dampak merokok bagi kesehatan

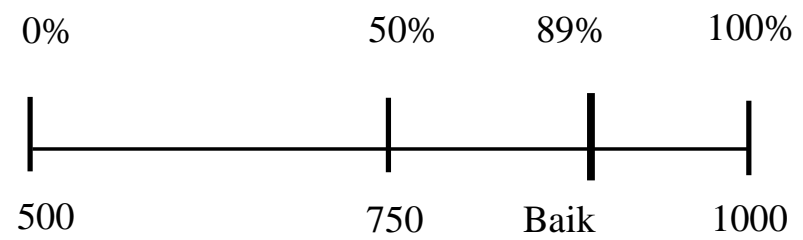

Gambar 2. Skala hasil pengukuran tingkat pengetahuan responden tentang dampak merokok bagi kesehatan gigi.

gigi tergolong baik.

Tabel 7. Distribusi frekuensi tingkat pengetahuan responden tentang dampak merokok terhadap jaringan periodontal.

\begin{tabular}{|c|c|c|c|c|}
\hline \multirow[b]{2}{*}{ No. } & \multirow[b]{2}{*}{ Pertanyaan } & \multicolumn{2}{|c|}{ Jawaban } & \multirow{2}{*}{$\begin{array}{c}\text { Skor } \\
\text { Penilaian }\end{array}$} \\
\hline & & Tahu & $\begin{array}{l}\text { Tidak } \\
\text { Tahu }\end{array}$ & \\
\hline 1. & $\begin{array}{l}\text { Tahukah anda merokok dapat berpengaruh pada kesehatan } \\
\text { gingiva? }\end{array}$ & 59 & 41 & 159 \\
\hline 2. & $\begin{array}{l}\text { Tahukah anda merokok dapat menyebabkan gingiva mudah } \\
\text { berdarah? }\end{array}$ & 32 & 68 & 132 \\
\hline 3. & $\begin{array}{l}\text { Tahukah anda merokok dapat berpengaruh pada jaringan } \\
\text { periodontal/jaringan penunjang gigi? }\end{array}$ & 52 & 48 & 152 \\
\hline 4. & $\begin{array}{l}\text { Tahukah anda bau mulut pada perokok di samping akibat nikotin } \\
\text { pada asap rokok, juga akibat kerusakan/gangguan pada jaringan } \\
\text { periodontal (jaringan penunjang gigi)? }\end{array}$ & 37 & 63 & 137 \\
\hline 5 & $\begin{array}{l}\text { Tahukah anda perdarahan gingiva pada perokok dapat } \\
\text { disebabkan karena gangguan/kerusakan jaringan periodontal } \\
\text { akibat merokok? }\end{array}$ & 17 & 83 & 117 \\
\hline 6. & $\begin{array}{l}\text { Tahukah anda gigi goyang pada perokok dapat disebabkan } \\
\text { karena gangguan/kerusakan jaringan periodontal/jaringan } \\
\text { penunjang gigi akibat merokok? }\end{array}$ & 21 & 79 & 113 \\
\hline
\end{tabular}

Berdasarkan hasil perhitungan skor penilaian keseluruhan responden, maka tingkat pengetahuan responden tentang dampak merokok bagi kesehatan jaringan periodontal memperoleh skor 810 dengan persentase $68 \%$.Batas skor terendah dari kelompok pertanyaan ini yaitu 600 dan skor tertinggi yaitu 1200.Skala hasil perhitungan yang diperoleh dapat dilihat pada Gambar 3, bahwa tingkat pengetahuan responden tentang dampak merokok bagi kesehatan jaringan periodontal tergolong baik.

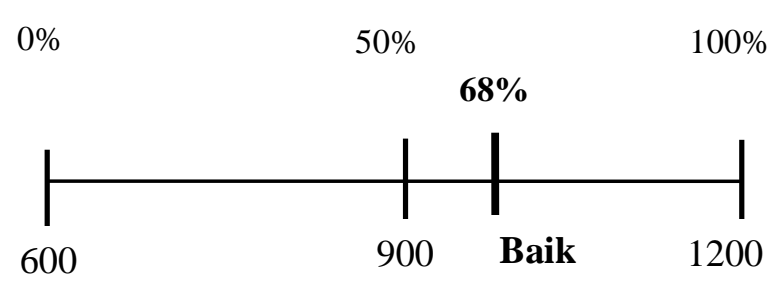

Gambar 3. Skala hasil pengukuran tingkat pengetahuan responden tentang dampak merokok bagi kesehatan jaringan periodontal. 
Jurnal e-GiGi (eG), Volume 2, Nomor 2, Juli-Desember 2014

Tabel 8. Distribusi frekuensi tingkat pengetahuan responden tentang dampak merokok terhadap kesehatan jaringan mukosa mulut.

\begin{tabular}{|c|c|c|c|c|}
\hline \multirow[b]{2}{*}{ No. } & \multirow[b]{2}{*}{ Pertanyaan } & \multicolumn{2}{|c|}{ Jawaban } & \multirow{2}{*}{$\begin{array}{c}\text { Skor } \\
\text { Penilaian }\end{array}$} \\
\hline & & Tahu & $\begin{array}{l}\text { Tidak } \\
\text { Tahu }\end{array}$ & \\
\hline 1. & $\begin{array}{l}\text { Tahukah anda merokok dapat berpengaruh pada jaringan } \\
\text { lunak/mukosa mulut? }\end{array}$ & 43 & 57 & 143 \\
\hline 2. & $\begin{array}{l}\text { Tahukah anda merokok dapat menyebabkan kanker rongga } \\
\text { mulut? }\end{array}$ & 40 & 60 & 140 \\
\hline \multirow[t]{2}{*}{3.} & $\begin{array}{l}\text { Tahukah anda kanker rongga mulut terjadi akibat adanya } \\
\text { perubahan jaringan akibat iritasi yang terus menerus karena } \\
\text { merokok? }\end{array}$ & 52 & 44 & 148 \\
\hline & & & Total Skor & 431 \\
\hline
\end{tabular}

Berdasarkan hasil perhitungan skor penilaian, maka tingkat pengetahuan responden tentang dampak merokok bagi kesehatan jaringan mukosa mulut memperoleh skor 431 dengan persentase 72\%.Batas skor terendah dari kelompok pertanyaan ini yaitu 300 dan skor tertinggi yaitu 600.Skala hasil perhitungan yang diperoleh dapat dilihat pada Gambar 4, bahwa tingkat pengetahuan responden tentang dampak merokok bagi kesehatan jaringan mukosa mulut tergolong baik.

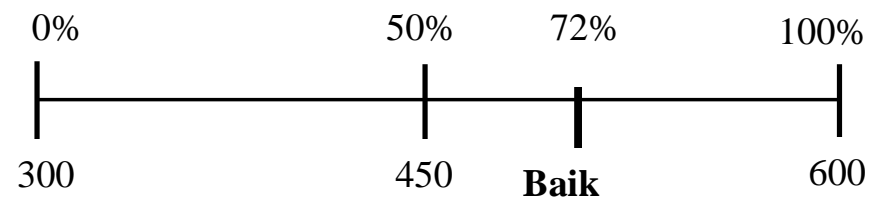

Gambar 4. Skala pengukuran tingkat pengetahuan tentang dampak merokok bagi kesehatan jaringan mukosa mulut.

Tabel 9. Distribusi tingkat pengetahuan dampak merokok bagi kesehatan gigi dan mulut

\begin{tabular}{|c|c|c|c|}
\hline No. & Pengetahuan & Persentase Penilaian & Kategori \\
\hline 1 & $\begin{array}{l}\text { Dampak merokok bagi kesehatan gigi \& mulut } \\
\text { secara umum }\end{array}$ & $96 \%$ & Baik \\
\hline 2 & Dampak merokok bagi kesehatan gigi & $89 \%$ & Baik \\
\hline 3 & $\begin{array}{l}\text { Dampak merokok bagi kesehatan jaringan } \\
\text { periodontal }\end{array}$ & $68 \%$ & Baik \\
\hline \multirow[t]{2}{*}{4} & $\begin{array}{l}\text { Dampak merokok bagi kesehatan jaringan } \\
\text { mukosa mulut }\end{array}$ & $72 \%$ & Baik \\
\hline & Rata-Rata Penilaian & $81 \%$ & Baik \\
\hline
\end{tabular}

Berdasarkan hasil perhitungan skor penilaian responden secara keseluruhan, maka tingkat pengetahuan responden tentang dampak merokok bagi kesehatan gigi dan mulut diperoleh skor sebesar 2898 dengan persentase $81 \%$. Batas skor terendah yaitu 1800 dan skor tertinggi yaitu 3600.Skala hasil perhitungan yang diperoleh dapat dilihat pada Gambar 5, secara keseluruhan tingkat pengetahuan tentang dampak merokok bagi kesehatan gigi dan mulut termasuk dalam kategori baik.

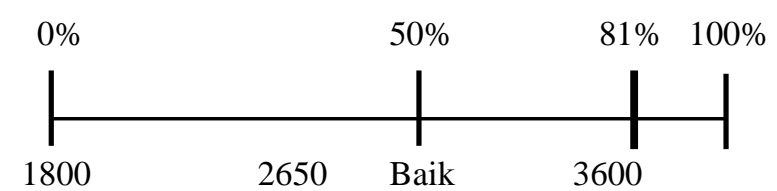

Gambar 5. Skala pengukuran tingkat pengetahuan tentang dampak merokok bagi kesehatan gigi dan mulut. 


\section{BAHASAN}

Dalam penelitian ini rata-rata perolehan skor tingkat pengetahuan responden tentang dampak merokok bagi kesehatan gigi dan mulut secara keseluruhan termasuk pada kategori baik (81\%).Pengetahuan ini meliputi pengetahuan tentang dampak merokok bagi kesehatan gigi dan mulut secara umum, dampak merokok bagi kesehatan gigi, dampak merokok bagi kesehatan jaringan periodontal, dan dampak merokok bagi kesehatan jaringan mukosa mulut.

Hasil penelitian ini menunjukkan bahwa hampir seluruh responden memiliki pengetahuan yang baik mengenai dampak merokok bagi kesehatan gigi dan mulut secara umum, tingkatan pengetahuan responden mencapai 96\%.Hal ini bisa diterima secara logika karena informasi tentang bahaya merokok begitu mudahnya diperoleh masyarakat termasuk responden. Banyaknya iklan tentang bahaya merokok yang terpampang di jalanan umum, serta berbagai informasi yang ada di media cetak, media elektronik maupun media internet dapat menyebabkan responden memiliki tingkat pengetahuan yang baik.

Terbentuknya pengetahuan responden tentang bahaya merokok bagi kesehatan, juga dapat diperoleh lewat pendidikan nonformal di rumah, karena merupakan hal yang umum orangtua melarang anakanaknya untuk merokok walaupun alasannya bermacam-macam. Pemahamanpemahaman yang diberikan orangtua di rumah dapat memengaruhi pengetahuan responden. Pelarangan terhadap merokok juga dilakukan di sekolah-sekolah, bahkan dewasa ini larangan merokok di tempattempat umum sudah diberlakukan. ${ }^{10} \mathrm{Hal}$ ini juga didukung oleh penelitian yang dilakukan Zakiah Darajat pada tahun 2013, tentang pelaksanaan peraturan kawasan bebas rokok di tempat-tempat umum sebagai perwujudan hak atas kesehatan masyarakat. Dalam penelitiannya merokok merupakan suatu perilaku yang tidak sehat, selain berbahaya bagi diri sendiri juga berbahaya terhadap lingkungan sekitar. ${ }^{11}$ Keadaan ini menggambarkan bahwa bahaya merokok sudah umum diketahui oleh masyarakat.

Pada penelitian ini diperoleh hasil yang menunjukkan pengetahuan responden tentang dampak merokok terhadap kesehatan gigi mencapai 89\%. Dampak merokok bagi kesehatan gigi merupakan pengetahuan yang bersifat umum. Berbagai informasi tentang kesehatan gigi secara umum mudah diperoleh masyarakat termasuk responden dan turut berpengaruh pada pengetahuan yang dimiliki responden. Hal ini dapat dipengaruhi juga oleh tingkat pendidikan responden. Responden pada penelitian ini adalah siswa SMA, yang memiliki pengetahuan yang sudah terbentuk sejak sekolah dasar. Di samping itu remaja pada kelompok usia ini ditandai dengan berkembangnya kemampuan berpikir yang baru. Rangsangan berupa informasi yang mudah diperoleh akibat kemajuan teknologi di bidang informasi, memengaruhi tingkat pengetahuan responden. Beragam informasi yang diperoleh termasuk informasi tentang dampak merokok bagi kesehatan gigi turut membentuk pengetahuan responden. Hal ini sesuai berdasarkan teori Mubarak pada tahun 2007, kemudahan dalam memperoleh informasi dapat membantu mempercepat seseorang untuk memperoleh pengetahuan yang baru. ${ }^{12}$ Usia 15-17 tahun merupakan usia remaja pertengahan. Pada kelompok usia ini remaja memiliki ciri mulai berkembangnya kematangan tingkah laku. Remaja mulai belajar mengendalikan impulsivitas dan membuat keputusan-keputusan awal sesuai tujuan yang ingin dicapai. ${ }^{13}$

Pengetahuan responden tentang dampak merokok bagi kesehatan jaringan periodontal bukan tergolong pengetahuan yang sifatnya umum seperti pengetahuan tentang dampak merokok bagi kesehatan gigi dan mulut secara umum serta pengetahuan tentang dampak merokok bagi kesehatan gigi. Pengetahuan tentang dampak merokok bagi kesehatan jaringan periodontal merupakan pengetahuan yang tergolong cukup tinggi, karena lebih spesifik ke pengetahuan di bidang kedokteran gigi. Hasil yang diperoleh menunjukkan bahwa responden telah memiliki pengetahuan yang 
baik, walaupun capaian tingkatannya hanya 68\%. Tingginya pengetahuan responden dapat dipengaruhi oleh tingkat intelektual siswa. Hal ini dikarenakan SMA Negeri 1 Manado merupakan salah satu sekolah unggulan yang sarat dengan prestasi dan merupakan salah satu SMA favorit di kota Manado. Siswa sekolah ini umumnya merupakan siswa yang berprestasi semasa pendidikan di tingkat SMP, sehingga kemampuan yang dimiliki siswa dalam penyerapan informasi turut menentukan tingkatan pengetahuan yang dimiliki.

Pengetahuan tentang dampak merokok bagi kesehatan jaringan mukosa mulut juga tidak tergolong dalam pengetahuan yang sifatnya umum. Hasil penelitian ini menggambarkan pencapaian tingkat pengetahuan responden yang tidak jauh berbeda (72\%) dengan tingkat pengetahuan mengenai dampak merokok bagi kesehatan jaringan periodontal. Kemampuan memahami responden selain dapat disebabkan oleh kemampuan intelektualnya juga dapat dipengaruhi oleh kondisi sosial ekonomi siswa. Pekerjaan orangtua siswa dalam penelitian ini hampir 90\% terdiri dari pegawai negeri dan pegawai swasta yang menggambarkan latar belakang kondisi sosial ekonomi responden. Untuk saat ini penghasilan pegawai negeri bisa dikatakan cukup baik, sehingga mampu mencukupi kebutuhan responden termasuk penyediaan alat komunikasi yang trendi. Alat komunikasi yang ada turut menunjang responden untuk memperoleh pengetahuan yang lebih luas lagi.

\section{SIMPULAN}

1. Tingkat pengetahuan siswa tentang dampak merokok bagi kesehatan gigi dan mulut secara umum tergolong baik.

2. Tingkat pengetahuan siswa tentang dampak merokok bagi kesehatan gigi tergolong baik.

3. Tingkat pengetahuan siswa tentang dampak merokok bagi kesehatan jaringan periodontal tergolong baik.
4. Tingkat pengetahuan siswa tentang dampak merokok bagi kesehatan jaringan mukosa mulut tergolong baik.

5. Tingkat pengetahuan siswa tentang dampak merokok bagi kesehatan gigi dan mulut secara keseluruhan tergolong baik.

\section{SARAN}

Data hasil penelitian betul-betul dapat dimanfaatkan oleh pihak puskesmas dalam bentuk kegiatan UKGS untuk menyusun program preventif dan promotif guna meningkatkan derajat kesehatan gigi dan mulut siswa.Diharapkan agar manfaat juga bisa dirasakan oleh masyarakat, disarankan masyarakat untuk dapat mengaplikasikan pengetahuan yang diperoleh lewat program preventif dan promotif dari puskesmas guna meningkatkan derajat kesehatan gigi dan mulut.Perlu adanya penelitian lebih lanjut dengan melibatkan populasi yang lebih luas untuk mengevaluasi tingkat pengetahuan tentang dampak merokok bagi kesehatan gigi dan mulut.

\section{DAFTAR PUSTAKA}

1. WHO. WHO Report on the global tobacco epidemic.2008.

2. Abdullah., Naseem A., Qureshi. The global youth tobacco survey. [online] 2007 [cited 2013 Maret 12]; Available from:URL: http://www.satcp.com/newsite/user/arabic news/126YTS.pdf

3. Kementerian Kesehatan Republik Indonesia. Anak remaja rentan menjadi perokok pemula. [cited 2013 Maret 12]; Available from:URL:http://www.depkes.go.id/.

4. Kementerian Kesehatan Republik Indonesia. Indonesia bukan Surga rokok. [cited 2013 April 25] Available from:URL:http://www. promkes. depkes.go.id/.

5. Kementerian Kesehatan Republik Indonesia. Riset kesehatan dasar. Jakarta: Badan Penelitian dan Pengembangan Kesehatan; 2010.

6. Komalasari, D. dan Helmi, AF. Faktor-faktor penyebab perilaku merokok pada remaja. Jurnal Psikologi Universitas Gadjah Mada. Vol.3 No.1.2005. h.37-47. 
Novitasari, Wowor, Kaunang; Gambaran Tingkat Pengetahuan Siswa SMA Negeri 1...

7. Husodo, SM. Jumlah leukosit air ludah para perokok. Majalah Kesehatan Gigi Indonesia. Vol.1 No.06 Juni 2005. h.18

8. Natamiharja, LB. Kebiasaan merokok dan karies spesifik pada sopir-sopir di Medan. Dentika jurnal, Vol.6, No.2. 2005. h.284-5.

9. Triswanto, S. Stop Merokok Yogyakarta: Progresif Books. 2007.

10. Kementerian Kesehatan Republik Indonesia. Pedoman teknis pengembangan kawasan tanpa rokok. [internet] 2014. [cited at: 2014 Agu 12]. Available from http://www. depkes.go.id
11. Darajat Z. Pelaksanaan peraturan kawasan bebas asap rokok pada tempat umum sebagai perwujudan hak atas kesehatan masyarakat. Jakarta: Bumi Aksara. 2008

12. Mubarak W. Ilmu keperawatan komunitas 2 . Jakarta: Sagung Seto. 2006

13. Kurniati A. Gambaran kebiasaan merokok dengan profil tekanan darah pada mahasiswa perokok laki-laki usia 18-22 tahun. Jurnal Kesehatan Masyarakat. Vol.1, No.2 2012. h. 251-6. 